\title{
DESAIN MODEL BASIS DATA OBYEK PARIWISATA PROVINSI JAWA TENGAH STUDI KASUS DI KABUPATEN MAGELANG
}

\author{
Wasino $^{1}$ \\ wasino@fti.untar.ac.id
}

\author{
Jap Tji Beng ${ }^{2}$ \\ t.jap@untar.ac.id
}

\author{
Desi Arisandi ${ }^{3}$ \\ desi@fti.untar.ac.id
}

\begin{abstract}
Magelang District is implementing the tourism development program that consists of: marketing development, tourism destination development, partnership development, and tourism infrastructure development. Data about tourism in Magelang regency has not been stored correctly according to the rules of database normalization, with redudancy data storage, including the data that stored and informed online. A good information system should be supported by accurate data and stored on a database that has been normalized, so that data can be read by the system or a different program with different goals and views. Based on the analysis of data obtained in Magelang District, there are several the same ways and the same and the different way of storing and displaying information tourism objects. Normalization process conduct on the obtained data until the 3rd normal form to eliminate the partial dependencies and transitive dependencies. The result of the reseach is a database model.
\end{abstract}

Keywords: database normalization, redudancy, dependencies (partial \& transitive), database model.

\section{Pendahuluan}

Prospek pengembangan pariwisata di Indonesia pada masa sekarang ini sangat strategis dengan penambahan destinasi pariwisata dan meningkatnya investasi pariwisata yang menjadikan pariwisata sebagai faktor penambah pendapatan ekspor, penciptaan lapangan kerja, dan pengembangan usaha yang mendukung pariwisata semakin maju. Perkembangan pariwisata ini harus didorong dengan pengembangan sarana promosi yang efektif diarahkan secara tepat kepada para wisatawan baik wisatawan nusantara (wisnu) maupun wisatawan mancanegara (wisman). Salah satu destinasi pariwisata di Jawa Tengah yang banyak dikunjungi wisnu dan wisman adalah obyek wisata yang ada di Kabupaten Magelang, secara khusus adalah obyek wisata sejarah dan budaya (candi).

Sebuah sistem informasi yang baik harus didukung oleh data yang akurat dan disimpan pada basis data yang telah dinormalisasikan, sehingga data dapat dibaca oleh sistem atau program aplikasi yang berbeda dengan tujuan berbeda, dan melalui pandangan yang berbeda. Data tentang wisata di Kabupaten Magelang tentu memiliki karakteristik yang berbeda dan teRLEtak di daerah yang juga berlainan tempat, selain itu data wisata tersebut tentu memiliki kategori atau jenis wisata yang berlainan. Beberapa pertanyaan mengenai data wisata berikut ini: (a) normalisasi data sampai bentuk ke berapa supaya duplikasi data dapat dihindari, (b) bagaimana hubungan antara satu data dengan data lainnya, (c) kapan dan bagaimana data harus disimpan untuk mendukung implementasi sistem.

\footnotetext{
${ }^{1}$ Sistem Informasi, Fakultas Teknologi Informasi, Universitas Tarumanagara

${ }^{2}$ Sistem Informasi, Fakultas Teknologi Informasi, Universitas Tarumanagara

${ }^{3}$ Sistem Informasi, Fakultas Teknologi Informasi, Universitas Tarumanagara
} 


\section{Landasan Teori}

\subsection{Pariwisata}

Pariwisata adalah kumpulan kegiatan, industri dan jasa yang memberikan layanan pengalaman perjalanan, di dalamnya ada layanan transportasi, akomodasi, makan dan minum, pusat jajanan, bisnis hiburan, fasilitas kegiatan dan jasa perhotelan lain yang disediakan untuk individu atau kelompok yang berpergian dari rumah ke tujuan tertentu (www. prm-nau.edu, 2013).

Pariwisata adalah tentang kegiatan orang-orang dari rumah atau tempat mereka bekerja untuk sementara waktu pada lingkungan yang mereka kenal sebagai upaya supaya merasa baik dengan mendapatkan fasilitas dan pelayanan yang memenuhi kebutuhan mereka. (ofobruku, 2013)

\subsection{Model Data}

Model data adalah koleksi terpadu dari konsep untuk menggambarkan dan memanipulasi data, hubungan antar data, dan batasan pada data dalam sebuah organisasi (Connolly, 2010). Data dapat terdiri dari beberapa bentuk, jenis dan sifat sebagai representasi suatu kejadian atau sebagai fakta yang belum diolah dibentuk sebagai sebuah model. Sebuah model adalah representasi dari benda, fakta atau kejadian nyata dan hubungan yang terjadi. Sebuah model data merupakan gambaran dari organisasi itu sendiri. Ini harus memiliki konsep dasar dan notasi yang memungkinkan desainer basis data dan pengguna akhir memiliki pemahanan yang jelas dan akurat tentang data organisasi (Connolly, 2010).

Model data adalah pola atau sistem secara grafis yang digunakan untuk menangkap sifat dan hubungan antar data yang digunakan pada berbagai level atau tingkat abstraksi data (Hoffer, 2011). Supaya setiap pemakai data mengerti dengan baik sifat data, maka pemodelan data merupakan cara yang baik untuk menjelaskan kepada pemakai sehingga dapat melihat data secara logis. Pemodelan data pada penelitian ini menggunakan model relasional yang dilakukan dalam tahap analisis dan desain.

\subsection{Sistem Basis Data}

Dalam kehidupan sehari-hari, basis data merupakan bagian yang terintegrasi dan secara tidak sadar kita menggunakannya. Merancang basis data yang benar merupakan dasar untuk membangun basis data yang memenuhi kebutuhan pengguna. Basis data adalah sebuah kumpulan besar data yang dapat digunakan secara bersamaan oleh banyak departemen dan pengguna. Semua item-item data pada sebuah basis data bukanlah file-file terpisah dengan adanya kemungkinan duplikasi data, tetapi lebih diintegrasikan dengan jumlah duplikasi yang seminimal mungkin.

Model data relasional adalah sebuah model yang didasarkan pada konsep relasi matematika. Dalam model data relasional, data dan hubungan yang direpresentasikan sebagai tabel, masing-masing diberi nomor kolom dengan nama yang unik yaitu nama atribut yang tidak boleh sama pada setiap kolom (Connolly, 2010). Basis data model relasional adalah basis data yang merepresentasikan data sebagai sebuah kumpulan dari tabel di mana semua hubungan data diwakili oleh nilai yang digunakan bersama dalam tabel yang berhubungan (Hoffer, 2011).

\subsection{Normalisasi}

Normalisasi adalah sebuah teknik untuk menghasilkan satu himpunan dari relasi dengan properti diperlukan sesuai kebutuhan data perusahaan. Normalisasi adalah suatu teknik yang dapat digunakan pada setiap tahap dalam melakukan desain basis data. Normalisasi juga diartikan sebagai suatu teknik untuk menganalisis relasi berdasarkan kunci utamanya (primary key) atau kunci kandidat (candidate key) dan menganalisis ketergantungan fungsional (Connolly, 2010). Teknik ini melibatkan serangkaian aturan yang dapat digunakan untuk menguji relasi sehingga basis data dapat dinormalisasi untuk tingkat apapun. Tiga bentuk relasi (disebut juga sebagai tabel) yang normal dan digunakan dalam penelitian ini adalah bentuk normal pertama (1NF), bentuk normal kedua (2NF), dan bentuk normal ketiga (3NF). 
Pendekatan dalam normalisasi terdapat 2 bentuk, yaitu pendekatan bottom up dan top down, dan dalam penelitian ini menggunakan pendekatan bottom up yaitu dengan memeriksa sumber data yang diperoleh dalam tahap pengumpulan kebutuhan untuk analisis.

\subsection{Ketergantungan Fungsional}

Ketergantungan fungsional adalah sebuah sifat yang menunjukkan bagaimana atribut berhubungan dengan atribut lainnya. Ketika ketergantungan fungsional muncul, ketergantungan itu dispesifikasikan sebagai batasan antara antribut (Connolly, 2010). Dalam penelitian ini, normalisasi dilakukan dengan menghilangkan ketergantungan fungsional yang bersifat parsial dan transitif.

Ketergantungan fungsional menggambarkan hubungan antara atribut dengan atribut lainnya dalam sebuah relasi. Jika A dan B adalah atribut dari relasi R, B secara fungsional bergantung pada $\mathrm{A}$ (dilambangkan $\mathrm{A} \rightarrow \mathrm{B}$ ), jika setiap nilai $\mathrm{A}$ dikaitkan dengan tepat satu nilai B. (A dan B bisa saja terdiri dari satu atribut atau lebih satu atribut).

Ketergantungan fungsional $\mathrm{A} \rightarrow \mathrm{B}$ adalah ketergantungan fungsional penuh apabila penghilangan setiap atribut dari A menghsilkan tiadanya ketergantungan lagi. Ketergantungan fungsional A - B memiliki ketergantungan yang bersifat parsial apabila ada beberapa atribut yang dapat dihilangkan dari A namun ketergantungannya masih ada.

Ketergantungan transitif merupakan ketergantungan dari beberapa atribut pada atribut lain yang bukan primary key. Sebuah kondisi dimana A, B, dan C adalah atribut dari sebuah relasi yang mana jika $\mathrm{A} \rightarrow \mathrm{B}$ dan $\mathrm{B} \rightarrow \mathrm{C}$, maka $\mathrm{C}$ adalah atribut yang bergantung secara transitif pada A melalui B. Pada penelitian ini, normalisasi data dilakukan dengan menghilangkan sifat ketergantungan parsial dan keterganungan transitif untuk menghasilkan normalisasi bentuk ke-3.

\section{Pengambilan dan Pengumpulan Data}

Fakta atau data mentah sangat penting untuk ditemukan selama proses pembangunan sistem basis data dalam tahap awal siklus hidup pengembangan sisem termasuk dalam perencanaan basis data, pendefinisian sistem, dan tahap analisis. Dalam pengumpulan fakta ini digunakan teknik fact-finding, yiatu sebuah teknik yang digunakan dalam pembangunan basis data sebagai sebuah proses formal menggunakan teknik seperti wawancara, memeriksa dokumen, pengamatan terhadap proses, dan perekaman data digital. Gambar direkam dengan foto digital sedangkan koordinat peta direkam dengan GPS format derajat, menit, dan detik.

Berikut ini adalah 4 contoh data obyek wisata, kegiatan dan kuliner yang ada di Kabupaten Magelang. Data ini diperoleh dengan cara mengukur jarak antar obyek melalui rute yang ditempuh peneliti, mengambil gambar dengan kamera, merekam koordinat peta dengan GPS, dan melakukan wawancara langsung kepada pengelola atau penanggung jawab obyek yang dikunjungi.

\section{a. Wisata Alam Ketep Pass}

Obyek wisata ini berada di desa Ketep, kecamatan Sawangan, kabupaten Magelang dengan letak puncaknya berada pada bukit Sawangan sehingga obyek wisata ini dikategorikan sebagai obyek wisata alam. Obyek wisata ini dinamakan ketep karena berada di desa Ketep dengan luas area kurang lebih $8.000 \mathrm{~m}^{2}$, dan ketinggian $1.170 \mathrm{~m}$ dpl. Obyek wisata ini diresmikan oleh Presiden Megawati pada tanggal 17 Oktober 2002 sebagai kawasan wisata jalur SSB (Solo Selo Borobudur). Jarak obyek wisata ini ke arah pertigaan Salatiga - Ketep - Magelang adalah 9 km, ke arah Candi Lumbung 6 km, dan dari Kota Magelang $17 \mathrm{~km}$. Fasilitas yang ada di obyek wisata ini antara lain: Gardu Pandang, Vulkano Theater tempat pemutaran film dokumentasi meletusnya gunung merapi, Vulkano Centre tempat memamerkan miniatur gunung merapi dan bebatuan hasil letusan, Pelataran Panca Arga, Restaurant Panca Arga, dan fasilitas tempat Ibadah dan tempat istirahat. 


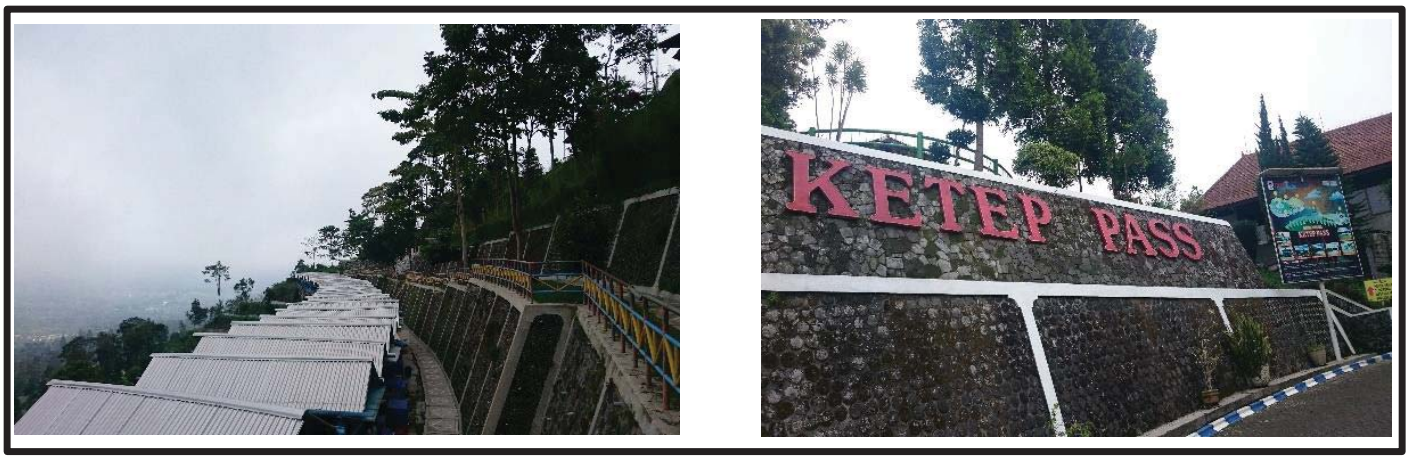

Gambar 1. Foto Obyek Wisata Ketep Pass

Koordinat GPS S: $07^{\circ} 29^{\prime} 40.8^{\prime \prime} \mathrm{E}: 110^{\circ} 22$ '52.3”

\section{b. Candi Mendut}

Candi Mendut merupakan candi bercorak keagamaan Budha Mahayana yang didirikan pada masa pemerintahan Raja Indra dari dinasti Saylendra. Hal ini dibuktikan dengan prasasti karang tengah yang berangka tahun 824 masehi. Prasasti tersebut menyebutkan bahwa Raja Indra telah membangun bangunan suci bernama 'crimad venuwana' yang memiliki arti bangunan suci di hutan bambu. Menurut J.G. de Casparis ahli arkeologi dari Belanda, kata ini dihubungkan dengan pendirian candi Mendut. Candi Mendut berada di desa Mendut, kecamatan Mungkid, kabupaten Magelang berjarak 19 km dari candi Lumbung, dan berjarak $37 \mathrm{~km}$ dari stasiun tugu yogyakarta.

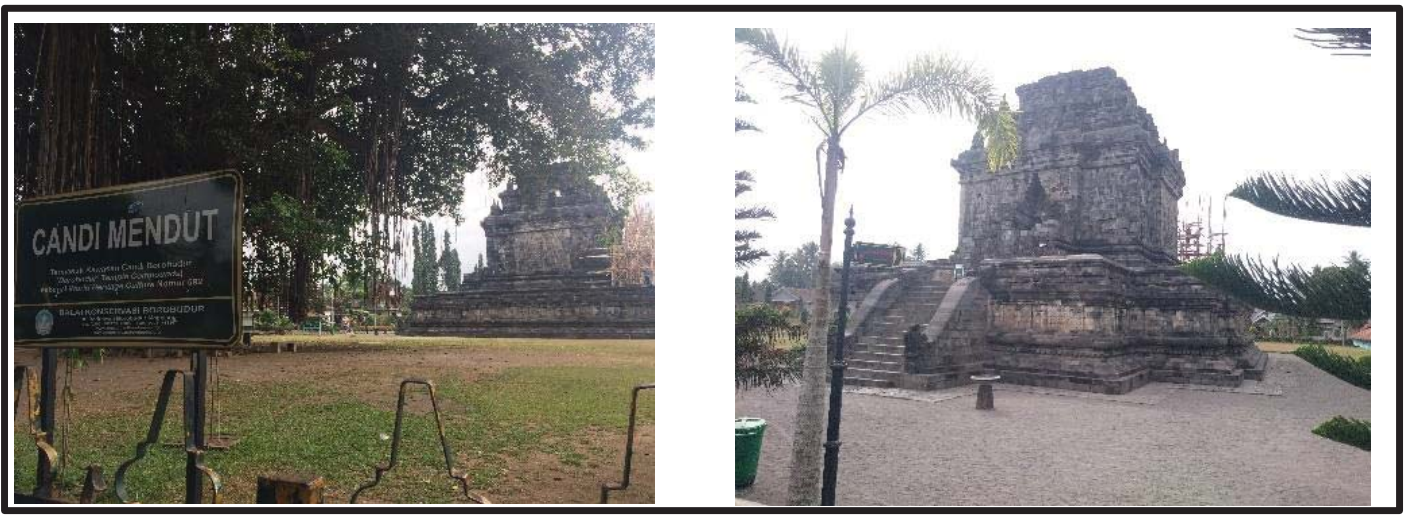

Gambar 2. Foto Candi Mendut

Koordinat GPS S: $07^{\circ} 36^{\prime} 20.0^{\prime \prime} \mathrm{E}: 110^{\circ} 13^{\prime} 48.2^{\prime \prime}$

Kumpulan data tentang obyek wisata yang diperoleh dan telah disederhanakan dari beberapa sampel data harus ditransformasikan (diubah bentuknya) ke dalam format tabel dalam baris dan kolom. Sampel obyek wisata yang diambil dari beberapa lokasi memiliki data dan informasi yang berbeda, dan data tersebut disimpan ke dalam baris dan kolom pada tabel yang belum berada pada keadaan normal karena terjadinya repeating group, sehingga keadaan yang demikian harus dihilangkan dengan membuatnya dalam bentuk normal seperti ditunjukkan pada Tabel 1.

Tabel 1.

Data Obyek Wisata (dalam bentuk normal, NF1) dengan menghilangkan repeating group.

\begin{tabular}{|c|c|c|c|c|c|c|c|}
\hline Nama obyek & $\begin{array}{l}\text { Kate } \\
\text { gori }\end{array}$ & Alamat Obyek & $\begin{array}{c}\text { Foto } \\
\text { Obyek }\end{array}$ & $\begin{array}{l}\text { Koordinat } \\
\text { Peta }\end{array}$ & $\begin{array}{c}\text { Jarak } \\
\text { Ke }\end{array}$ & $\begin{array}{l}\text { Sejarah dan } \\
\text { Keterangan }\end{array}$ & $\begin{array}{c}\text { Fasilitas } \\
\text { Obyek }\end{array}$ \\
\hline Ketep Pass & Alam & $\begin{array}{l}\text { Jalan Blabak, desa } \\
\text { Ketep, kecamatan } \\
\text { Sawangan, kabupaten } \\
\text { Magelang }\end{array}$ & Foto1 & $\begin{array}{l}\text { S: } 07^{\circ} 29^{\prime} 40.8^{\prime \prime} \\
\text { E: } 110^{\circ} 22^{\prime} 52.3^{\prime \prime}\end{array}$ & $\begin{array}{l}\text { Candi } \\
\text { lumbung } \\
6 \mathrm{~km}\end{array}$ & $\begin{array}{l}\text { Obyek wisata ini } \\
\text { dinamakan ketep } \\
\text { karena berada ..... }\end{array}$ & $\begin{array}{l}\text { Gardu } \\
\text { Pandang }\end{array}$ \\
\hline
\end{tabular}


Desain Model Basis Data Obyek Pariwisata

Provinsi Jawa Tengah Studi Kasus Di Kabupaten Magelang

\begin{tabular}{|c|c|c|c|c|c|c|c|}
\hline Nama obyek & $\begin{array}{r}\text { Kate } \\
\text { gori }\end{array}$ & Alamat Obyek & $\begin{array}{l}\text { Foto } \\
\text { Obyek }\end{array}$ & $\begin{array}{c}\text { Koordinat } \\
\text { Peta }\end{array}$ & $\begin{array}{c}\text { Jarak } \\
\text { Ke }\end{array}$ & $\begin{array}{l}\text { Sejarah dan } \\
\text { Keterangan }\end{array}$ & $\begin{array}{c}\text { Fasilitas } \\
\text { Obyek }\end{array}$ \\
\hline Ketep Pass & Alam & $\begin{array}{l}\text { Jalan Blabak, desa } \\
\text { Ketep, kecamatan } \\
\text { Sawangan, kabupaten } \\
\text { Magelang }\end{array}$ & Fotol & $\begin{array}{l}\text { S: } 07^{\circ} 29^{\prime} 40.8^{\prime \prime} \\
\text { E:110²2'52.3” }\end{array}$ & $\begin{array}{l}\text { Candi } \\
\text { lumbung } \\
6 \mathrm{~km}\end{array}$ & $\begin{array}{l}\text { Obyek wisata ini } \\
\text { dinamakan ketep } \\
\text { karena berada ..... }\end{array}$ & $\begin{array}{l}\text { Vulkano } \\
\text { Theater }\end{array}$ \\
\hline$\ldots$. & $\ldots$. & $\ldots \ldots$ & $\ldots$. & $\ldots .$. & $\ldots \ldots$ & $\ldots .$. & ....... \\
\hline Ketep Pass & Alam & $\begin{array}{l}\text { Jalan Blabak, desa } \\
\text { Ketep, kecamatan } \\
\text { Sawangan, kabupaten } \\
\text { Magelang }\end{array}$ & Foto2 & $\begin{array}{l}\text { S: } 07^{\circ} 29^{\prime} 40.8^{\prime \prime} \\
\text { E:110²2'52.3”' }\end{array}$ & $\begin{array}{l}\text { Candi } \\
\text { lumbung } \\
6 \mathrm{~km}\end{array}$ & $\begin{array}{l}\text { Obyek wisata ini } \\
\text { dinamakan ketep } \\
\text { karena berada ..... }\end{array}$ & $\begin{array}{l}\text { Vulkano } \\
\text { Theater }\end{array}$ \\
\hline$\ldots .$. & $\ldots \ldots$ & $\ldots \ldots$ & $\ldots .$. & $\ldots \ldots$ & $\ldots \ldots$ & $\ldots \ldots$ & ....... \\
\hline $\begin{array}{l}\text { Candi } \\
\text { Lumbung }\end{array}$ & $\begin{array}{l}\text { Sejarah } \\
\text { dan } \\
\text { Budaya }\end{array}$ & $\begin{array}{l}\text { Desa } \\
\text { Kronggowasan, } \\
\text { kecamatan } \\
\text { Lumbung, } \\
\text { Kabupaten } \\
\text { Magelang } \\
\end{array}$ & Foto 1 & $\begin{array}{l}\text { S: } 07^{\circ} 31 ' 33.1^{\prime \prime} \\
\text { E:110²0'51.7' }\end{array}$ & $\begin{array}{l}\text { Ketep } \\
\text { Pass } 6 \\
\text { km, }\end{array}$ & $\begin{array}{lr}\text { Candi } & \text { ini } \\
\text { merupakan } & \text { candi } \\
\text { yang dibuat } & \text { pada } \\
\text { masa } & \text { Raja } \\
\text { Mataram } & \text { yang } \\
\text { ke-8 ..... } & \end{array}$ & - \\
\hline $\begin{array}{l}\text { Candi } \\
\text { Lumbung }\end{array}$ & $\begin{array}{l}\text { Sejarah } \\
\text { dan } \\
\text { Budaya }\end{array}$ & $\begin{array}{l}\text { Desa } \\
\text { Kronggowasan, } \\
\text { kecamatan } \\
\text { Lumbung, } \\
\text { Kabupaten } \\
\text { Magelang }\end{array}$ & Foto 2 & $\begin{array}{l}\text { S: } 07^{\circ} 31^{\prime} 33.1^{\prime \prime} \\
\text { E:110²0'51.7" }\end{array}$ & $\begin{array}{l}\text { Ketep } \\
\text { Pass } 6 \\
\text { km, }\end{array}$ & $\begin{array}{lr}\text { Candi } & \text { ini } \\
\text { merupakan } & \text { candi } \\
\text { yang dibuat } & \text { pada } \\
\text { masa } & \text { Raja } \\
\text { Mataram } & \text { yang } \\
\text { ke-8 ..... } & \end{array}$ & - \\
\hline f... & $\ldots \ldots$ & $\ldots$. & $\ldots$. & $\ldots .$. & $\ldots .$. & … & $\ldots .$. \\
\hline $\begin{array}{l}\text { Museum } \\
\text { Samudraraksa }\end{array}$ & Museum & $\begin{array}{l}\text { desa Borobudur, } \\
\text { kecamatan } \\
\text { Borobudur, } \\
\text { kabupaten Magelang }\end{array}$ & Foto 1 & - & - & $\begin{array}{l}\text { Museum } \\
\text { Samudraraksa } \\
\text { dibuat dan } \\
\text { diresmikan oleh } \\
\text { Menko Kesra .... }\end{array}$ & - \\
\hline $\begin{array}{l}\text { Museum } \\
\text { Samudraraksa }\end{array}$ & Museum & $\begin{array}{l}\text { desa Borobudur, } \\
\text { kecamatan } \\
\text { Borobudur, } \\
\text { kabupaten Magelang }\end{array}$ & Foto 2 & - & - & $\begin{array}{l}\text { Museum } \\
\text { Samudraraksa } \\
\text { dibuat dan } \\
\text { diresmikan oleh } \\
\text { Menko Kesra .... }\end{array}$ & - \\
\hline$\ldots .$. & ..... & ..... & $\ldots .$. & $\ldots .$. & $\ldots$. & $\ldots$. & $\ldots .$. \\
\hline
\end{tabular}

\section{c. Informasi Kegiatan atau Event}

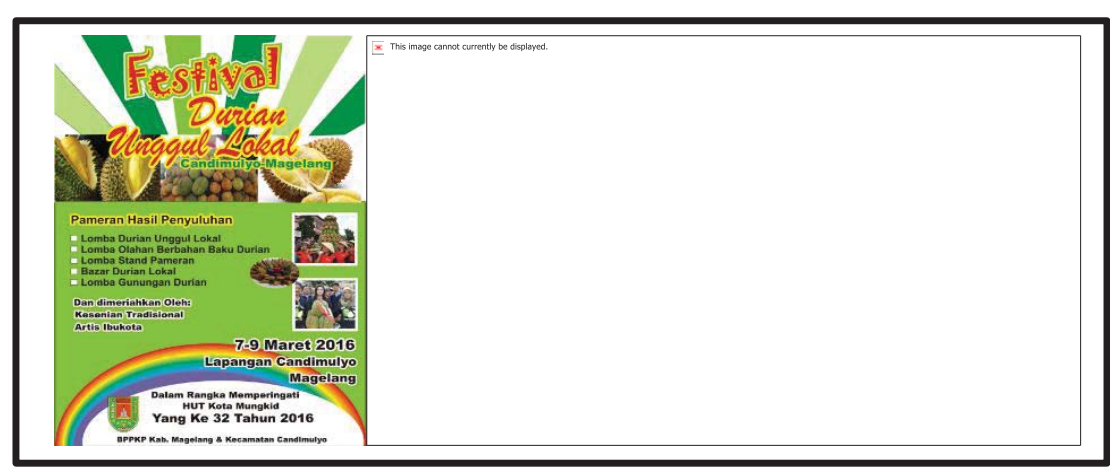

Gambar 3. Brosur Kegiatan atau Event

Informasi pada Gambar 3 harus diubah bentuknya kedalam format tabel seperti pada Tabel 2, tabel tesebut masih dalam bentuk tidak normal. Pada dokumen lain yang diperoleh seperti berita kegiatan atau berita event, daftar restaurant, dan brosur restaurant juga terindetifikasi atributnya seperti pada Tabel 3 dan Tabel 4. Data pada tabel tersebut juga belum berada pada kondisi normal, karena terdapatnya repeating group.

\section{Normalisasi Data}

Normalisasi merupakan sebuah teknik dalam merancang basis data, dimulai dari memeriksa hubungan antar data atau antar atribut untuk mengetahu ketergantungan fungsional. Atribut ini menjelaskan beberapa ciri dari data dan hubungannya antar data yang penting. Dalam desain basis data ini, normalisasi dilakukan sampai dengan tingkat ke-3 yaitu dengan menghilangkan ketergantungan transitif. Tabel 2 adalah contoh sebagai tabel yang belum normal, pada tabel tersebut teridentifikasi terjadinya repeating group yaitu pada atribut 
acara, dan kontak karena dalam satu sel terdapat lebih dari 1 data. Sebagai contoh terjadinya repeating group pada atribut kontak berisi Emma: 085643556634, dan Langen: 085643773524 . Tabel tersebut harus diubah kedalam bentuk normal atau normal ke-1 sehingga setiap nilai unik tersimpan pada satu baris dan kolom (sel) dengan cara menghilangkan repeating group.

Tabel 2.

Kegiatan atau Event (dalam bentuk belum normal)

\begin{tabular}{|c|c|c|c|c|c|c|c|}
\hline $\begin{array}{l}\text { Nama } \\
\text { event }\end{array}$ & Waktu & Tempat & Penyelenggara & Acara & Hiburan & Keterangan & Kontak \\
\hline $\begin{array}{l}\text { Festival } \\
\text { Durian } \\
\text { Unggul } \\
\text { Lokal }\end{array}$ & $\begin{array}{l}7-9 \\
\text { Maret } \\
2016\end{array}$ & $\begin{array}{l}\text { Lapangan } \\
\text { Candimulyo } \\
\text { Magelang }\end{array}$ & $\begin{array}{l}\text { BPPKP } \\
\text { Kabupatn } \\
\text { Magelang dan } \\
\text { Kecamatan } \\
\text { Candimulyo }\end{array}$ & $\begin{array}{l}\text { Lomba durian } \\
\text { unggul lokal, } \\
\text { Lomba } \\
\text { olahraga } \\
\text { berbahan baku } \\
\text { durian, Lomba } \\
\text { stand pameran }\end{array}$ & $\begin{array}{l}\text { Kesenian } \\
\text { tradisional } \\
\text { artis } \\
\text { ibukota }\end{array}$ & $\begin{array}{l}\text { Dalam } \\
\text { rangka } \\
\text { memperingati } \\
\text { HUT Kota } \\
\text { Mungkid } \\
\text { yang ke-32 } \\
\text { tahun 2016. }\end{array}$ & - \\
\hline $\begin{array}{l}\text { Lomba } \\
\text { Gede } \\
\text { Gedean } \\
\text { Durian }\end{array}$ & $\begin{array}{l}19 \\
\text { Maret } \\
2015\end{array}$ & $\begin{array}{l}\text { Lapangan } \\
\text { Candimulyo } \\
\text { Magelang }\end{array}$ & $\begin{array}{l}\text { BPPKP } \\
\text { Kabupatn } \\
\text { Magelang dan } \\
\text { Kecamatan } \\
\text { Mungkid } \\
\end{array}$ & $\begin{array}{lr}\text { Lomba } & \text { gede } \\
\text { gedean } & \text { durian } \\
\text { diukur } & \text { dari } \\
\text { volume } & \text { isi } \\
\text { lingkaran. } & \\
\end{array}$ & - & $\begin{array}{l}\text { Syarat dan } \\
\text { ketentuan: } \\
\ldots . . .\end{array}$ & $\begin{array}{l}\text { Emma: } \\
\text { 085643556634 } \\
\text { Langen: } \\
085643773524\end{array}$ \\
\hline$\ldots$ & $\ldots$ & $\ldots$ & .... & .... & $\ldots$ & $\ldots$ & $\ldots$ \\
\hline
\end{tabular}

Tabel 3, 4 dan 5 berikut ini merupakan tabel yang sudah dalam bentuk normal, dimana proses penghilangan repeating group sudah dilakukan, sehingga tabel tersebut tidak mengandung repeating group, yaitu dengan menghilangkan komponen yang berulang.

Tabel 3.

Kegiatan atau Event bentuk Normal ke-1 (Penghilangan Repeating Gorup berdasarkan Tabel 2)

\begin{tabular}{|c|c|c|c|c|c|c|c|}
\hline $\begin{array}{l}\text { Nama } \\
\text { event }\end{array}$ & Waktu & Tempat & Penyelenggara & Acara & Hiburan & Keterangan & Kontak \\
\hline $\begin{array}{l}\text { Festival } \\
\text { Durian } \\
\text { Unggul } \\
\text { Lokal }\end{array}$ & $\begin{array}{l}7-9 \\
\text { Maret } \\
2016\end{array}$ & $\begin{array}{l}\text { Lapangan } \\
\text { Candimulyo } \\
\text { Magelang }\end{array}$ & $\begin{array}{l}\text { BPPKP } \\
\text { Kabupatn } \\
\text { Magelang dan } \\
\text { Kecamatan } \\
\text { Candimulyo }\end{array}$ & $\begin{array}{l}\text { Lomba } \\
\text { durian } \\
\text { unggul } \\
\text { lokal }\end{array}$ & $\begin{array}{l}\text { Kesenian } \\
\text { tradisional } \\
\text { artis } \\
\text { ibukota }\end{array}$ & $\begin{array}{l}\text { Dalam rangka } \\
\text { memperingati } \\
\text { HUT Kota } \\
\text { Mungkid yang } \\
\text { ke-32 tahun } \\
2016 .\end{array}$ & - \\
\hline $\begin{array}{l}\text { Festival } \\
\text { Durian } \\
\text { Unggul } \\
\text { Lokal }\end{array}$ & $\begin{array}{l}7-9 \\
\text { Maret } \\
2016\end{array}$ & $\begin{array}{l}\text { Lapangan } \\
\text { Candimulyo } \\
\text { Magelang }\end{array}$ & $\begin{array}{l}\text { BPPKP } \\
\text { Kabupatn } \\
\text { Magelang dan } \\
\text { Kecamatan } \\
\text { Candimulyo }\end{array}$ & $\begin{array}{l}\text { Lomba } \\
\text { olahraga } \\
\text { berbahan } \\
\text { baku } \\
\text { durian }\end{array}$ & $\begin{array}{l}\text { Kesenian } \\
\text { tradisional } \\
\text { artis } \\
\text { ibukota }\end{array}$ & $\begin{array}{l}\text { Dalam rangka } \\
\text { memperingati } \\
\text { HUT Kota } \\
\text { Mungkid yang } \\
\text { ke-32 tahun } \\
2016 .\end{array}$ & - \\
\hline $\begin{array}{l}\text { Festival } \\
\text { Durian } \\
\text { Unggul } \\
\text { Lokal }\end{array}$ & $\begin{array}{l}7-9 \\
\text { Maret } \\
2016\end{array}$ & $\begin{array}{l}\text { Lapangan } \\
\text { Candimulyo } \\
\text { Magelang }\end{array}$ & $\begin{array}{l}\text { BPPKP } \\
\text { Kabupatn } \\
\text { Magelang dan } \\
\text { Kecamatan } \\
\text { Candimulyo }\end{array}$ & $\begin{array}{l}\text { Lomba } \\
\text { stand } \\
\text { pameran }\end{array}$ & $\begin{array}{l}\text { Kesenian } \\
\text { tradisional } \\
\text { artis } \\
\text { ibukota }\end{array}$ & $\begin{array}{l}\text { Dalam rangka } \\
\text { memperingati } \\
\text { HUT Kota } \\
\text { Mungkid yang } \\
\text { ke-32 tahun } \\
2016 .\end{array}$ & - \\
\hline $\begin{array}{l}\text { Lomba } \\
\text { Gede } \\
\text { Gedean } \\
\text { Durian }\end{array}$ & $\begin{array}{l}19 \\
\text { Maret } \\
2015\end{array}$ & $\begin{array}{l}\text { Lapangan } \\
\text { Candimulyo } \\
\text { Magelang }\end{array}$ & $\begin{array}{l}\text { BPPKP } \\
\text { Kabupatn } \\
\text { Magelang dan } \\
\text { Kecamatan } \\
\text { Mungkid }\end{array}$ & $\begin{array}{l}\text { Lomba } \\
\text { gede } \\
\text { gedean } \\
\text { durian } \\
\text { diukur dari } \\
\text { volume isi } \\
\text { lingkaran. }\end{array}$ & - & $\begin{array}{l}\text { Syarat dan } \\
\text { ketentuan: ...... }\end{array}$ & $\begin{array}{l}\text { Emma: } \\
085643556634\end{array}$ \\
\hline $\begin{array}{l}\text { Lomba } \\
\text { Gede } \\
\text { Gedean } \\
\text { Durian }\end{array}$ & $\begin{array}{l}19 \\
\text { Maret } \\
2015\end{array}$ & $\begin{array}{l}\text { Lapangan } \\
\text { Candimulyo } \\
\text { Magelang }\end{array}$ & $\begin{array}{l}\text { BPPKP } \\
\text { Kabupatn } \\
\text { Magelang dan } \\
\text { Kecamatan } \\
\text { Mungkid }\end{array}$ & $\begin{array}{l}\text { Lomba } \\
\text { gede } \\
\text { gedean } \\
\text { durian } \\
\text { diukur dari } \\
\text { volume isi } \\
\text { lingkaran. } \\
\end{array}$ & - & $\begin{array}{l}\text { Syarat dan } \\
\text { ketentuan: ...... }\end{array}$ & $\begin{array}{l}\text { Langen: } \\
085643773524\end{array}$ \\
\hline$\ldots$. & $\ldots$. & $\ldots$. & $\ldots$. & $\ldots$ & $\ldots$. & $\ldots$. & $\ldots$ \\
\hline
\end{tabular}


Tabel 4.

Berita Pelaksanaan Kegiatan bentuk Normal ke-1

\begin{tabular}{|c|c|c|c|c|c|c|c|}
\hline Judulberita & Penulis & Tgljamberita & Kabupaten & Tglevent & Isiberita & Fotoberita & Judulfoto \\
\hline $\begin{array}{l}\text { Festival } \\
\text { durian } \\
\text { candimulyo } \\
\text { makin eksis }\end{array}$ & $\begin{array}{l}\text { Bagian } \\
\text { humas } \\
\text { dan } \\
\text { protokol }\end{array}$ & $\begin{array}{l}\text { 10 March } 2016 \\
07: 59\end{array}$ & Magelang & $8 / 3 / 2016$ & $\begin{array}{l}\text { Keberadaan } \\
\text { festival durian } \\
\text { di candimulyo } \\
\text { dari tahun ke } \\
\text { ahun semakin } \\
\text { eksis dan } \\
\text { mendapatkan }\end{array}$ & Foto 1 & $\begin{array}{l}\text { Arak arakan } \\
\text { gunungan.... }\end{array}$ \\
\hline $\begin{array}{l}\text { Festival } \\
\text { durian } \\
\text { candimulyo } \\
\text { makin eksis }\end{array}$ & $\begin{array}{l}\text { Bagian } \\
\text { humas } \\
\text { dan } \\
\text { protokol }\end{array}$ & $\begin{array}{l}\text { 10 March } 2016 \\
07: 59\end{array}$ & Magelang & $8 / 3 / 2016$ & $\begin{array}{l}\text { Keberadaan } \\
\text { festival durian } \\
\text { di candimulyo } \\
\text { dari tahun ke } \\
\text { ahun semakin } \\
\text { eksis dan } \\
\text { mendapatkan }\end{array}$ & foto 2 & $\begin{array}{l}\text { Warga } \\
\text { berebut }\end{array}$ \\
\hline$\ldots$ & $\ldots$ & $\ldots$ & $\ldots$ & $\ldots$ & $\ldots$ & $\ldots$ & $\ldots$ \\
\hline
\end{tabular}

Tabel 5 .

Data Restaurant bentuk Normal ke-1

\begin{tabular}{|l|l|l|}
\hline namaResto & alamatResto & NoTelpon \\
\hline Orang Utan Resto & J1 Mayor Kusen km2,4 dusun Sikluwih Pabelan Mungkid Kabupaten Magelang & $0293-789322$ \\
\hline$\ldots . .$. & $\ldots \ldots .$. & $\ldots .$. \\
\hline Sekar Kedathon & J1 Palbapang Borobudur km 2,5 desa Pabelan Kecamatan Mungkid & $0293-789429$ \\
\hline Sekar Kedathon & J1 Palbapang Borobudur km 2,5 desa Pabelan Kecamatan Mungkid & $0293-789429$ \\
\hline$\ldots . .$. & $\ldots \ldots .$. & $\ldots .$. \\
\hline
\end{tabular}

Tabel 6 .

Informasi Restaurant bentuk Normal ke-1

\begin{tabular}{|c|c|c|c|c|c|c|c|c|c|}
\hline $\begin{array}{l}\text { Judulin } \\
\text { fo }\end{array}$ & $\begin{array}{l}\text { tglinf } \\
0\end{array}$ & $\begin{array}{l}\text { namares } \\
\text { to }\end{array}$ & $\begin{array}{l}\text { foto } \\
\mathrm{R}\end{array}$ & beritaResto & $\begin{array}{l}\text { alamatRe } \\
\text { sto }\end{array}$ & $\begin{array}{l}\text { tlpRes } \\
\text { to }\end{array}$ & $\begin{array}{l}\text { Pemil } \\
\text { ik }\end{array}$ & $\begin{array}{l}\text { hpPemili } \\
\text { k }\end{array}$ & Email \\
\hline $\begin{array}{l}\text { Selamat } \\
\text { datang di } \\
\text { Sekar } \\
\text { Kedatho } \\
\text { n .... }\end{array}$ & $\begin{array}{l}\text { March } \\
6, \\
2016\end{array}$ & $\begin{array}{l}\text { Sekar } \\
\text { Kedathon }\end{array}$ & Foto & $\begin{array}{l}\text { Sekar } \\
\text { Kedhaton } \\
\text { Restaurant ad } \\
\text { alah tempat } \\
\text {..... }\end{array}$ & $\begin{array}{l}\text { Jl. Raya } \\
\text { Borobudur } \\
\mathrm{km} . \quad 2,5 \\
\text { Mungkid, } \\
\text { Magelang }\end{array}$ & $\begin{array}{l}0293 \\
386868\end{array}$ & $\begin{array}{l}\text { Betta } \\
\text { Farah, } \\
\text { SE }\end{array}$ & $\begin{array}{l}081125187 \\
4\end{array}$ & $\begin{array}{l}\text { betta.farah@yahoo. } \\
\text { com }\end{array}$ \\
\hline $\begin{array}{l}\text { Selamat } \\
\text { datang di } \\
\text { Sekar } \\
\text { Kedatho } \\
\text { n .... }\end{array}$ & $\begin{array}{l}\text { March } \\
6, \\
2016\end{array}$ & $\begin{array}{l}\text { Sekar } \\
\text { Kedathon }\end{array}$ & Foto & $\begin{array}{l}\text { Sekar } \\
\text { Kedhaton } \\
\text { Restaurant ad } \\
\text { alah tempat } \\
\text {..... }\end{array}$ & $\begin{array}{l}\text { Jl. Raya } \\
\text { Borobudur } \\
\text { km. 2,5 } \\
\text { Mungkid, } \\
\text { Magelang }\end{array}$ & $\begin{array}{l}0293 \\
386005\end{array}$ & $\begin{array}{l}\text { Betta } \\
\text { Farah, } \\
\text { SE }\end{array}$ & $\begin{array}{l}085100418 \\
424\end{array}$ & $\begin{array}{l}\text { betta.farah@yahoo. } \\
\text { com }\end{array}$ \\
\hline$\ldots$ & $\ldots$ & $\ldots$ & $\ldots$ & $\ldots$ & $\ldots$ & $\ldots$ & $\ldots$ & $\ldots$ & \\
\hline
\end{tabular}

Nama kolom atau atribut seperti yang ditunjukkan pada Tabel 1 sampai dengan 6 terdiri dari beberapa sifat atribut seperti simple attribute, composite attribute, dan multivalued attribute. Atribut yang bersifat single valued attribute dan derived attribute belum ada pada tabel tersebut. Pada Tabel 1 (alamatobyek, koordinatpeta, jarakke), Tabel 3 (tempat), pada Tabel 5 dan 6 (alamatresto) merupakan composite attribute yang isinya terdiri dari beberapa komponen nilai. Atribut ini dapat dibagi lagi untuk menghasilkan atribut yang lebih kecil dengan independensi data pada setiap atribut tersebut. Seperti pada atribut tempat dan atribut alamatobyek karena mengacu pada tampilan pengguna sebagai data yang dapat digunakan bersama dan tidak sebagai komponen individu.

Atribut tempat dibagi kedalam atribut yang lebih sederhana dengan lokasi, kecamatan, kabupaten, kemudian alamatobyek disederhanakan menjadi alamat, desa, kecamatan, kabupaten. Atribut koordinat peta juga merupakan composit attribute sehingga disederhanakan menjadi atribut koordinat gps-south, gps-east sedangkan atribut jarakke disederhanakan menjadi atribut tujuan, dan jarak-km. 
Tabel 7 sampai dengan 11 merupakan tabel hasil penyederhanaan compostie attribute menjadi simple attribute.

Tabel 7.

Penyederhanaan Atribut AlamatObyek (Tabel 1)

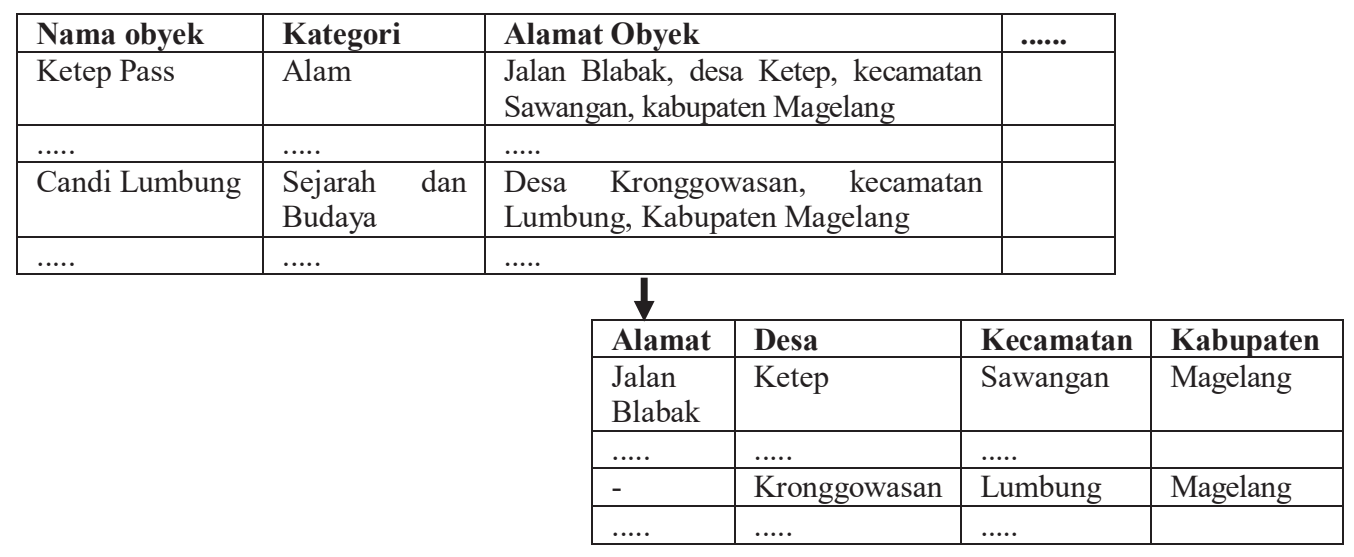

Atribut alamatobyek tidak simpel karena memiliki komponen nilai yang tidak tunggal, maka disederhanakan menjadi empat atribut yang memiliki nila simpel sehingga data tersebut dapat digunakan bersama. Atribut lain yang bersifat composite juga harus disederhanakan menjadi atribut yang bersifat simpel.

Tabel 8.

Penyederhanaan Atribut Koordinat Peta (Tabel 7)

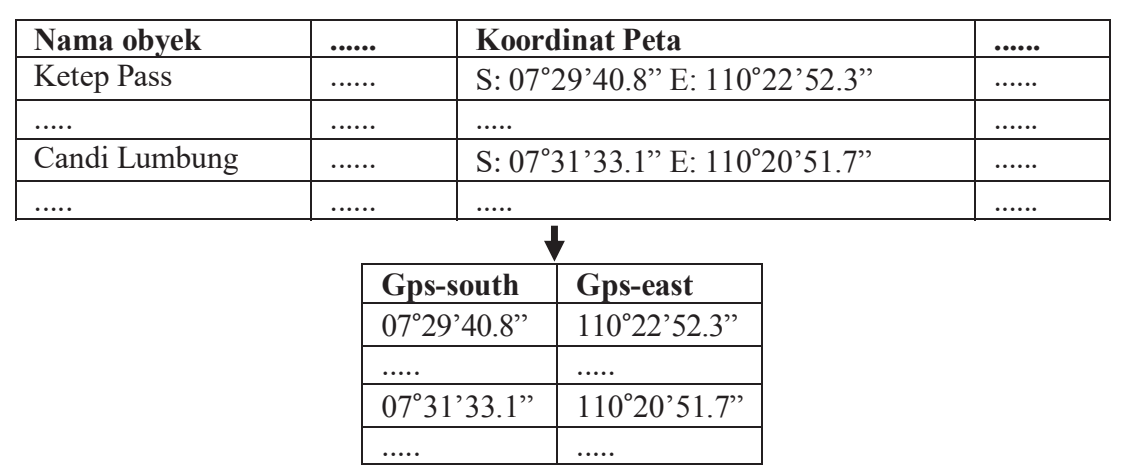

Tabel 9.

Penyederhanaan Atribut Jarak ke (Tabel 1)

\begin{tabular}{|c|c|c|c|c|}
\hline Nama obyek & ....... & \multicolumn{2}{|l|}{ Jarak ke } & ....... \\
\hline Ketep Pass & $\ldots . .$. & \multicolumn{2}{|c|}{ Candi lumbung $6 \mathrm{~km}$} & $\ldots . .$. \\
\hline$\ldots .$. & $\ldots . .$. & \multicolumn{2}{|l|}{$\ldots .}$. & $\ldots . .$. \\
\hline Candi Lumbung & $\ldots \ldots$ & \multicolumn{2}{|l|}{ Ketep Pass 6 km, } & $\ldots \ldots$ \\
\hline$\ldots$. & $\ldots \ldots$ & \multicolumn{2}{|l|}{..... } & $\ldots \ldots$. \\
\hline & & Tujuan & \multicolumn{2}{|c|}{ Jarak-KM } \\
\hline & & Candi Lumbung & \multicolumn{2}{|c|}{6} \\
\hline & & $\ldots \ldots$ & \multicolumn{2}{|c|}{$\ldots .}$. \\
\hline & & Ketep Pass & \multicolumn{2}{|c|}{6} \\
\hline & & ..... & \multicolumn{2}{|c|}{$\ldots .}$. \\
\hline
\end{tabular}


Tabel 10.

Penyederhanaan Atribut Tempat (Tabel 3)

\begin{tabular}{|c|c|c|c|c|}
\hline \multicolumn{2}{|l|}{ Nama event } & Waktu & Tempat & ........ \\
\hline \multicolumn{2}{|c|}{ Festival Durian Unggul Lokal } & 7-9 Maret 2016 & Lapangan Candimulyo Magelang & ........ \\
\hline \multicolumn{2}{|c|}{ Lomba Gede Gedean Durian } & 19 Maret 2015 & Lapangan Candimulyo Magelang & ........ \\
\hline Nama Tempat & Kecamatan & Kabupaten & & \\
\hline Lapangan & Candimulyo & Magelang & & \\
\hline$\ldots .$. & $\ldots .$. & & & \\
\hline
\end{tabular}

Tabel 11.

Penyederhanaan Atribut alamatResto (Tabel 6)

\begin{tabular}{|c|c|c|c|c|c|c|}
\hline \multicolumn{2}{|l|}{ Judulinfo } & \multicolumn{2}{|c|}{$\ldots . .}$. & \multicolumn{2}{|c|}{ alamatResto } & ........ \\
\hline \multicolumn{2}{|c|}{ Selamat datang di Sekar Kedathon .... } & \multicolumn{2}{|c|}{.......... } & \multicolumn{2}{|c|}{ Jl. Raya Borobudur km. 2,5 Mungkid, Magelang } & .......... \\
\hline \multicolumn{2}{|c|}{$\ldots$} & \multicolumn{2}{|c|}{$\ldots$} & \multicolumn{2}{|c|}{$\ldots$} & \\
\hline \multicolumn{7}{|c|}{ 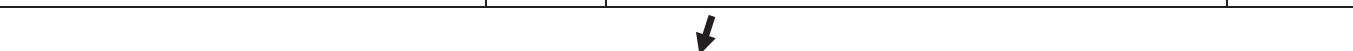 } \\
\hline Alamat & \multicolumn{2}{|c|}{ Desa } & \multirow{2}{*}{\multicolumn{2}{|c|}{$\begin{array}{l}\text { Kecamatan } \\
\text { Mungkid }\end{array}$}} & Kabupaten & \\
\hline Jl. Raya Borobudur km 2,5 & \multicolumn{2}{|c|}{ Borobudur } & & & Magelang & \\
\hline$\ldots .$. & \multicolumn{2}{|c|}{$\ldots}$. & \multicolumn{2}{|c|}{$\ldots}$. & ........ & \\
\hline
\end{tabular}

Setiap tabel haruslah memiliki primary key sebagai pengenal yang unik pada setiap baris pada tabel tersebut. Pengenal tersebut harus sebuah atribut atau gabungan atribut yang bersifat single valued yaitu atribut yang memegang nilai tunggal untuk setiap baris data. Atribut single valued biasanya ditambahkan oleh desainer basis data atau ditetapkan oleh sistem analis sebagai atribut pengenal yang memiliki nilai tunggal pada setiap kemunculan data pada tabel.

\section{Identifikasi Ketergantungan Fungsional}

Tabel 12 sampai dengan 14 merupakan tabel yang diperoleh dari proses penghilangan repeating group (isi dari sebuah atribut yang memiliki nilai lebih dari satu kemungkinan) dan proses penyederhanaan dari atribut yang bersifat composite attribute (isi dari sebuah atribut yang memiliki nilai tidak simpel terdiri dari lebih satu komponen nilai). Tabel tersebut telah normal pada bentuk ke-1 tetapi belum normal bentuk ke-2 karena adanya kerangkapan data sehingga harus diubah kedalam bentuk normal ke-2 dengan memperhatikan ketergantungan fungsional yang bersifat parsial.

Tabel 12.

Informasi Obyek Wisata bentuk Normal ke-1 dengan Penyederhanaan Atribut

\begin{tabular}{|c|c|c|c|c|c|c|c|c|c|c|c|c|}
\hline $\begin{array}{l}\text { Nama } \\
\text { obyek }\end{array}$ & $\begin{array}{l}\text { Kate } \\
\text { gori }\end{array}$ & $\begin{array}{l}\text { Ala } \\
\text { mat }\end{array}$ & Desa & $\begin{array}{l}\text { Keca } \\
\text { matan }\end{array}$ & $\begin{array}{l}\text { Kabu } \\
\text { paten }\end{array}$ & $\begin{array}{l}\text { Fot } \\
\text { o } \\
\text { Ob } \\
\text { yek }\end{array}$ & $\begin{array}{l}\text { Gps- } \\
\text { south }\end{array}$ & $\begin{array}{l}\text { Gps- } \\
\text { east }\end{array}$ & $\begin{array}{l}\text { Tuju } \\
\text { an }\end{array}$ & $\begin{array}{l}\text { Jar } \\
\text { ak } \\
\text { K } \\
\text { M }\end{array}$ & $\begin{array}{l}\text { Sejara } \\
\text { h dan } \\
\text { Ketera } \\
\text { ngan }\end{array}$ & $\begin{array}{l}\text { Fasil } \\
\text { itas } \\
\text { Oby } \\
\text { ek }\end{array}$ \\
\hline $\begin{array}{l}\text { Ketep } \\
\text { Pass }\end{array}$ & $\begin{array}{l}\text { Ala } \\
\mathrm{m}\end{array}$ & $\begin{array}{l}\text { Jala } \\
\mathrm{n} \\
\text { Blab } \\
\text { ak }\end{array}$ & Ketep & $\begin{array}{l}\text { Sawan } \\
\text { gan }\end{array}$ & $\begin{array}{l}\text { Magel } \\
\text { ang }\end{array}$ & $\begin{array}{l}\text { Fot } \\
\text { o1 }\end{array}$ & $\begin{array}{l}07^{\circ} 29^{\prime} \\
40.8^{\prime \prime}\end{array}$ & $\begin{array}{l}110^{\circ} 22^{\prime} \\
52.3^{\prime \prime}\end{array}$ & $\begin{array}{l}\text { Cand } \\
\text { i } \\
\text { Lum } \\
\text { bung }\end{array}$ & 6 & $\begin{array}{l}\text { Obyek } \\
\text { wisata } \\
\text { ini } \\
\text { dinama } \\
\text { kan } \\
\text { ketep } \\
\text { karena } \\
\text { berada } \\
. . . .\end{array}$ & $\begin{array}{l}\text { Gard } \\
\mathrm{u} \\
\text { Pand } \\
\text { ang }\end{array}$ \\
\hline $\begin{array}{l}\text { Ketep } \\
\text { Pass }\end{array}$ & $\begin{array}{l}\text { Ala } \\
\mathrm{m}\end{array}$ & $\begin{array}{l}\text { Jala } \\
\mathrm{n} \\
\text { Blab } \\
\text { ak }\end{array}$ & Ketep & $\begin{array}{l}\text { Sawan } \\
\text { gan }\end{array}$ & $\begin{array}{l}\text { Magel } \\
\text { ang }\end{array}$ & $\begin{array}{l}\text { Fot } \\
\text { o1 }\end{array}$ & $\begin{array}{l}07^{\circ} 29^{\prime} \\
40.8^{\prime \prime}\end{array}$ & $\begin{array}{l}110^{\circ} 22^{\prime} \\
52.3^{\prime \prime}\end{array}$ & $\begin{array}{l}\text { Cand } \\
\text { i } \\
\text { Lum } \\
\text { bung }\end{array}$ & 6 & $\begin{array}{l}\text { Obyek } \\
\text { wisata } \\
\text { ini } \\
\text { dinama } \\
\text { kan } \\
\text { ketep } \\
\text { karena }\end{array}$ & $\begin{array}{l}\text { Vulk } \\
\text { ano } \\
\text { Thea } \\
\text { ter }\end{array}$ \\
\hline
\end{tabular}




\begin{tabular}{|c|c|c|c|c|c|c|c|c|c|c|c|c|}
\hline $\begin{array}{l}\text { Nama } \\
\text { obyek }\end{array}$ & $\begin{array}{l}\text { Kate } \\
\text { gori }\end{array}$ & $\begin{array}{l}\text { Ala } \\
\text { mat }\end{array}$ & Desa & $\begin{array}{l}\text { Keca } \\
\text { matan }\end{array}$ & $\begin{array}{l}\text { Kabu } \\
\text { paten }\end{array}$ & $\begin{array}{l}\text { Fot } \\
\text { o } \\
\text { Ob } \\
\text { yek }\end{array}$ & $\begin{array}{l}\text { Gps- } \\
\text { south }\end{array}$ & $\begin{array}{l}\text { Gps- } \\
\text { east }\end{array}$ & $\begin{array}{l}\text { Tuju } \\
\text { an }\end{array}$ & $\begin{array}{l}\text { Jar } \\
\text { ak } \\
\text { K } \\
\text { M }\end{array}$ & $\begin{array}{l}\text { Sejara } \\
\text { h dan } \\
\text { Ketera } \\
\text { ngan }\end{array}$ & $\begin{array}{l}\text { Fasil } \\
\text { itas } \\
\text { Oby } \\
\text { ek }\end{array}$ \\
\hline & & & & & & & & & & & $\begin{array}{l}\text { berada } \\
\text {..... }\end{array}$ & \\
\hline$\ldots$. & $\ldots .$. & $\ldots \ldots$ & & & & $\ldots .$. & $\ldots .$. & & & $\ldots \ldots$ & $\ldots .$. & $\ldots \ldots$ \\
\hline $\begin{array}{l}\text { Ketep } \\
\text { Pass }\end{array}$ & $\begin{array}{l}\text { Ala } \\
\mathrm{m}\end{array}$ & $\begin{array}{l}\text { Jala } \\
\text { n } \\
\text { Blab } \\
\text { ak }\end{array}$ & Ketep & $\begin{array}{l}\text { Sawan } \\
\text { gan }\end{array}$ & $\begin{array}{l}\text { Magel } \\
\text { ang }\end{array}$ & $\begin{array}{l}\text { Fot } \\
\text { o1 }\end{array}$ & $\begin{array}{l}07^{\circ} 29^{\prime} \\
40.8^{\prime \prime}\end{array}$ & $\begin{array}{l}110^{\circ} 22^{\prime} \\
52.3^{\prime \prime}\end{array}$ & $\begin{array}{l}\text { Cand } \\
\text { i } \\
\text { Lum } \\
\text { bung }\end{array}$ & 6 & $\begin{array}{l}\text { Obyek } \\
\text { wisata } \\
\text { ini } \\
\text { dinama } \\
\text { kan } \\
\text { ketep } \\
\text { karena } \\
\text { berada } \\
\text {..... }\end{array}$ & $\begin{array}{l}\text { Gard } \\
\mathrm{u} \\
\text { Pand } \\
\text { ang }\end{array}$ \\
\hline $\begin{array}{l}\text { Ketep } \\
\text { Pass }\end{array}$ & $\begin{array}{l}\text { Ala } \\
\mathrm{m}\end{array}$ & $\begin{array}{l}\text { Jala } \\
\mathrm{n} \\
\text { Blab } \\
\text { ak }\end{array}$ & Ketep & $\begin{array}{l}\text { Sawan } \\
\text { gan }\end{array}$ & $\begin{array}{l}\text { Magel } \\
\text { ang }\end{array}$ & $\begin{array}{l}\text { Fot } \\
\text { ol }\end{array}$ & $\begin{array}{l}07^{\circ} 29^{\prime} \\
40.8^{\prime \prime}\end{array}$ & $\begin{array}{l}110^{\circ} 22^{\prime} \\
52.3^{\prime \prime}\end{array}$ & $\begin{array}{l}\text { Cand } \\
\text { i } \\
\text { Lum } \\
\text { bung }\end{array}$ & 6 & $\begin{array}{l}\text { Obyek } \\
\text { wisata } \\
\text { ini } \\
\text { dinama } \\
\text { kan } \\
\text { ketep } \\
\text { karena } \\
\text { berada } \\
\text {..... } \\
\end{array}$ & $\begin{array}{l}\text { Vulk } \\
\text { ano } \\
\text { Thea } \\
\text { ter }\end{array}$ \\
\hline$\ldots \ldots$ & $\ldots .$. & $\ldots \ldots$ & & & & $\ldots .$. & $\ldots \ldots$ & & & $\ldots \ldots$ & $\ldots .$. & $\ldots \ldots$ \\
\hline $\begin{array}{l}\text { Ketep } \\
\text { Pass }\end{array}$ & $\begin{array}{l}\text { Ala } \\
\mathrm{m}\end{array}$ & $\begin{array}{l}\text { Jala } \\
\text { n } \\
\text { Blab } \\
\text { ak }\end{array}$ & Ketep & $\begin{array}{l}\text { Sawan } \\
\text { gan }\end{array}$ & $\begin{array}{l}\text { Magel } \\
\text { ang }\end{array}$ & $\begin{array}{l}\text { Fot } \\
\text { o2 }\end{array}$ & $\begin{array}{l}07^{\circ} 29^{\prime} \\
40.8^{\prime \prime}\end{array}$ & $\begin{array}{l}110^{\circ} 22^{\prime} \\
52.3^{\prime \prime}\end{array}$ & $\begin{array}{l}\text { Cand } \\
\text { i } \\
\text { Lum } \\
\text { bung }\end{array}$ & 6 & $\begin{array}{l}\text { Obyek } \\
\text { wisata } \\
\text { ini } \\
\text { dinama } \\
\text { kan } \\
\text { ketep } \\
\text { karena } \\
\text { berada }\end{array}$ & $\begin{array}{l}\text { Gard } \\
\mathrm{u} \\
\text { Pand } \\
\text { ang }\end{array}$ \\
\hline $\begin{array}{l}\text { Ketep } \\
\text { Pass }\end{array}$ & $\begin{array}{l}\text { Ala } \\
\mathrm{m}\end{array}$ & $\begin{array}{l}\text { Jala } \\
\mathrm{n} \\
\text { Blab } \\
\text { ak }\end{array}$ & Ketep & $\begin{array}{l}\text { Sawan } \\
\text { gan }\end{array}$ & $\begin{array}{l}\text { Magel } \\
\text { ang }\end{array}$ & $\begin{array}{l}\text { Fot } \\
\mathrm{o} 2\end{array}$ & $\begin{array}{l}07^{\circ} 29^{\prime} \\
40.8^{\prime \prime}\end{array}$ & $\begin{array}{l}110^{\circ} 22^{\prime} \\
52.3^{\prime \prime}\end{array}$ & $\begin{array}{l}\text { Cand } \\
\text { i } \\
\text { Lum } \\
\text { bung }\end{array}$ & 6 & $\begin{array}{l}\text { Obyek } \\
\text { wisata } \\
\text { ini } \\
\text { dinama } \\
\text { kan } \\
\text { ketep } \\
\text { karena } \\
\text { berada } \\
\text {..... }\end{array}$ & $\begin{array}{l}\text { Vulk } \\
\text { ano } \\
\text { Thea } \\
\text { ter }\end{array}$ \\
\hline$\ldots .$. & $\ldots .$. & $\ldots .$. & & & & $\ldots .$. & $\ldots \ldots$ & & & $\ldots .$. & $\ldots .$. & $\ldots \ldots$ \\
\hline $\begin{array}{l}\text { Candi } \\
\text { Lumbu } \\
\text { ng }\end{array}$ & $\begin{array}{l}\text { Sejar } \\
\text { ah } \\
\text { dan } \\
\text { Buda } \\
\text { ya }\end{array}$ & - & $\begin{array}{l}\text { Krongg } \\
\text { owasan }\end{array}$ & $\begin{array}{l}\text { Lumb } \\
\text { ung }\end{array}$ & $\begin{array}{l}\text { Magel } \\
\text { ang }\end{array}$ & $\begin{array}{l}\text { Fot } \\
\text { o } 1\end{array}$ & $\begin{array}{l}07^{\circ} 31^{\prime} \\
33.1^{\prime \prime}\end{array}$ & $\begin{array}{l}110^{\circ} 20^{\prime} \\
51.7^{\prime \prime}\end{array}$ & $\begin{array}{l}\text { Kete } \\
\mathrm{p} \\
\text { Pass }\end{array}$ & 6 & $\begin{array}{l}\text { Candi } \\
\text { ini } \\
\text { merupa } \\
\text { kan } \\
\text { candi } \\
\text { yang } \\
\text { dibuat } \\
\text { pada } \\
\text { masa } \\
\text { Raja } \\
\text { Matara } \\
\text { m yang } \\
\text { ke-8 }\end{array}$ & - \\
\hline $\begin{array}{l}\text { Candi } \\
\text { Lumbu } \\
\text { ng }\end{array}$ & $\begin{array}{l}\text { Sejar } \\
\text { ah } \\
\text { dan } \\
\text { Buda } \\
\text { ya }\end{array}$ & - & $\begin{array}{l}\text { Krongg } \\
\text { owasan }\end{array}$ & $\begin{array}{l}\text { Lumb } \\
\text { ung }\end{array}$ & $\begin{array}{l}\text { Magel } \\
\text { ang }\end{array}$ & $\begin{array}{l}\text { Fot } \\
\text { o } 2\end{array}$ & $\begin{array}{l}07^{\circ} 31^{\prime} \\
33.1^{\prime \prime}\end{array}$ & $\begin{array}{l}110^{\circ} 20^{\prime} \\
51.7^{\prime \prime}\end{array}$ & $\begin{array}{l}\text { Kete } \\
\mathrm{p} \\
\text { Pass }\end{array}$ & 6 & $\begin{array}{l}\text { Candi } \\
\text { ini } \\
\text { merupa } \\
\text { kan } \\
\text { candi } \\
\text { yang } \\
\text { dibuat } \\
\text { pada } \\
\text { masa } \\
\text { Raja } \\
\text { Matara } \\
\text { m yang } \\
\text { ke-8 }\end{array}$ & - \\
\hline$\ldots .$. & $\ldots .$. & $\ldots$. & & & & $\ldots .$. & $\ldots .$. & & & $\ldots .$. & $\ldots .$. & $\ldots .$. \\
\hline $\begin{array}{l}\text { Museu } \\
\mathrm{m}\end{array}$ & $\begin{array}{l}\text { Mus } \\
\text { eum }\end{array}$ & - & $\begin{array}{l}\text { Borobud } \\
\text { ur }\end{array}$ & $\begin{array}{l}\text { Borob } \\
\text { udur }\end{array}$ & $\begin{array}{l}\text { Magel } \\
\text { ang }\end{array}$ & $\begin{array}{l}\text { Fot } \\
\text { o } 1\end{array}$ & - & & & - & $\begin{array}{l}\text { Museu } \\
\mathrm{m}\end{array}$ & - \\
\hline
\end{tabular}


Desain Model Basis Data Obyek Pariwisata Provinsi Jawa Tengah Studi Kasus Di Kabupaten Magelang

\begin{tabular}{|c|c|c|c|c|c|c|c|c|c|c|c|c|}
\hline $\begin{array}{l}\text { Nama } \\
\text { obyek }\end{array}$ & $\begin{array}{l}\text { Kate } \\
\text { gori }\end{array}$ & $\begin{array}{l}\text { Ala } \\
\text { mat }\end{array}$ & Desa & $\begin{array}{l}\text { Keca } \\
\text { matan }\end{array}$ & $\begin{array}{l}\text { Kabu } \\
\text { paten }\end{array}$ & $\begin{array}{l}\text { Fot } \\
\text { o } \\
\text { Ob } \\
\text { yek } \\
\end{array}$ & $\begin{array}{l}\text { Gps- } \\
\text { south }\end{array}$ & $\begin{array}{l}\text { Gps- } \\
\text { east }\end{array}$ & $\begin{array}{l}\text { Tuju } \\
\text { an }\end{array}$ & $\begin{array}{l}\text { Jar } \\
\text { ak } \\
\text { K } \\
\text { M } \\
\end{array}$ & $\begin{array}{l}\text { Sejara } \\
\text { h dan } \\
\text { Ketera } \\
\text { ngan }\end{array}$ & $\begin{array}{l}\text { Fasil } \\
\text { itas } \\
\text { Oby } \\
\text { ek }\end{array}$ \\
\hline $\begin{array}{l}\text { Samudr } \\
\text { araksa }\end{array}$ & & & & & & & & & & & $\begin{array}{l}\text { Samudr } \\
\text { araksa } \\
\text { dibuat } \\
\text { dan } \\
\text { diresmi } \\
\text { kan } \\
\text { oleh } \\
\text { Menko } \\
\text { Kesra } \\
\text {.... }\end{array}$ & \\
\hline $\begin{array}{l}\text { Museu } \\
\mathrm{m} \\
\text { Samudr } \\
\text { araksa }\end{array}$ & $\begin{array}{l}\text { Mus } \\
\text { eum }\end{array}$ & - & $\begin{array}{l}\text { Borobud } \\
\text { ur }\end{array}$ & $\begin{array}{l}\text { Borob } \\
\text { udur }\end{array}$ & $\begin{array}{l}\text { Magel } \\
\text { ang }\end{array}$ & $\begin{array}{l}\text { Fot } \\
\text { o } 2\end{array}$ & - & & & - & $\begin{array}{l}\text { Museu } \\
\mathrm{m} \\
\text { Samudr } \\
\text { araksa } \\
\text { dibuat } \\
\text { dan } \\
\text { diresmi } \\
\text { kan } \\
\text { oleh } \\
\text { Menko } \\
\text { Kesra } \\
\text {.... } \\
\end{array}$ & - \\
\hline$\ldots \ldots$ & $\ldots .$. & $\ldots$ & & & & $\ldots .$. & $\ldots$ & & & $\ldots$. & $\ldots$. & $\ldots \ldots$ \\
\hline
\end{tabular}

Tabel 13.

Kegiatan atau Event bentuk Normal ke-1 dengan Penyederhanaan Atribut

\begin{tabular}{|c|c|c|c|c|c|c|c|c|c|}
\hline $\begin{array}{l}\text { Nama } \\
\text { event }\end{array}$ & $\begin{array}{l}\text { Wakt } \\
\text { u }\end{array}$ & $\begin{array}{l}\text { Nama } \\
\text { Tempa } \\
\text { t }\end{array}$ & $\begin{array}{l}\text { Kecamat } \\
\text { an }\end{array}$ & $\begin{array}{l}\text { Kabupat } \\
\text { en }\end{array}$ & $\begin{array}{l}\text { Penyelengg } \\
\text { ara }\end{array}$ & Acara & $\begin{array}{l}\text { Hibura } \\
\text { n }\end{array}$ & $\begin{array}{l}\text { Keteranga } \\
\text { n }\end{array}$ & Kontak \\
\hline $\begin{array}{l}\text { Festiv } \\
\text { al } \\
\text { Duria } \\
\text { n } \\
\text { Ungg } \\
\text { ul } \\
\text { Lokal }\end{array}$ & $\begin{array}{l}7-9 \\
\text { Maret } \\
2016\end{array}$ & $\begin{array}{l}\text { Lapang } \\
\text { an }\end{array}$ & $\begin{array}{l}\text { Candimul } \\
\text { yo }\end{array}$ & $\begin{array}{l}\text { Magelan } \\
\mathrm{g}\end{array}$ & $\begin{array}{l}\text { BPPKP } \\
\text { Kabupatn } \\
\text { Magelang } \\
\text { dan } \\
\text { Kecamatan } \\
\text { Candimulyo }\end{array}$ & $\begin{array}{l}\text { Lomba } \\
\text { durian } \\
\text { unggul } \\
\text { lokal }\end{array}$ & $\begin{array}{l}\text { Kesenia } \\
\mathrm{n} \\
\text { tradisio } \\
\text { nal artis } \\
\text { ibukota }\end{array}$ & $\begin{array}{l}\text { Dalam } \\
\text { rangka } \\
\text { memperin } \\
\text { gati HUT } \\
\text { Kota } \\
\text { Mungkid } \\
\text { yang ke-32 } \\
\text { tahun } \\
2016 .\end{array}$ & - \\
\hline $\begin{array}{l}\text { Festiv } \\
\text { al } \\
\text { Duria } \\
\text { n } \\
\text { Ungg } \\
\text { ul } \\
\text { Lokal }\end{array}$ & $\begin{array}{l}7-9 \\
\text { Maret } \\
2016\end{array}$ & $\begin{array}{l}\text { Lapang } \\
\text { an }\end{array}$ & $\begin{array}{l}\text { Candimul } \\
\text { yo }\end{array}$ & $\begin{array}{l}\text { Magelan } \\
\mathrm{g}\end{array}$ & $\begin{array}{l}\text { BPPKP } \\
\text { Kabupatn } \\
\text { Magelang } \\
\text { dan } \\
\text { Kecamatan } \\
\text { Candimulyo }\end{array}$ & $\begin{array}{l}\text { Lomba } \\
\text { olahrag } \\
\text { a } \\
\text { berbaha } \\
\mathrm{n} \text { baku } \\
\text { durian }\end{array}$ & $\begin{array}{l}\text { Kesenia } \\
\mathrm{n} \\
\text { tradisio } \\
\text { nal artis } \\
\text { ibukota }\end{array}$ & $\begin{array}{l}\text { Dalam } \\
\text { rangka } \\
\text { memperin } \\
\text { gati HUT } \\
\text { Kota } \\
\text { Mungkid } \\
\text { yang ke-32 } \\
\text { tahun } \\
2016 . \\
\end{array}$ & - \\
\hline $\begin{array}{l}\text { Festiv } \\
\text { al } \\
\text { Duria } \\
\text { n } \\
\text { Ungg } \\
\text { ul } \\
\text { Lokal }\end{array}$ & $\begin{array}{l}7-9 \\
\text { Maret } \\
2016\end{array}$ & $\begin{array}{l}\text { Lapang } \\
\text { an }\end{array}$ & $\begin{array}{l}\text { Candimul } \\
\text { yo }\end{array}$ & $\begin{array}{l}\text { Magelan } \\
\mathrm{g}\end{array}$ & $\begin{array}{l}\text { BPPKP } \\
\text { Kabupatn } \\
\text { Magelang } \\
\text { dan } \\
\text { Kecamatan } \\
\text { Candimulyo }\end{array}$ & $\begin{array}{l}\text { Lomba } \\
\text { stand } \\
\text { pamera } \\
\mathrm{n}\end{array}$ & $\begin{array}{l}\text { Kesenia } \\
\mathrm{n} \\
\text { tradisio } \\
\text { nal artis } \\
\text { ibukota }\end{array}$ & $\begin{array}{l}\text { Dalam } \\
\text { rangka } \\
\text { memperin } \\
\text { gati HUT } \\
\text { Kota } \\
\text { Mungkid } \\
\text { yang ke-32 } \\
\text { tahun } \\
2016 .\end{array}$ & - \\
\hline $\begin{array}{l}\text { Lomb } \\
\text { a } \\
\text { Gede } \\
\text { Gedea } \\
\text { n } \\
\text { Duria } \\
n\end{array}$ & $\begin{array}{l}19 \\
\text { Maret } \\
2015\end{array}$ & $\begin{array}{l}\text { Lapang } \\
\text { an }\end{array}$ & $\begin{array}{l}\text { Candimul } \\
\text { yo }\end{array}$ & $\begin{array}{l}\text { Magelan } \\
\mathrm{g}\end{array}$ & $\begin{array}{l}\text { BPPKP } \\
\text { Kabupatn } \\
\text { Magelang } \\
\text { dan } \\
\text { Kecamatan } \\
\text { Mungkid }\end{array}$ & $\begin{array}{l}\text { Lomba } \\
\text { gede } \\
\text { gedean } \\
\text { durian } \\
\text { diukur } \\
\text { dari } \\
\text { volume } \\
\text { isi } \\
\text { lingkar } \\
\text { an. }\end{array}$ & - & $\begin{array}{l}\text { Syarat dan } \\
\text { ketentuan: } \\
\text {...... }\end{array}$ & $\begin{array}{l}\text { Emma: } \\
085643556 \\
634\end{array}$ \\
\hline
\end{tabular}




\begin{tabular}{|c|c|c|c|c|c|c|c|c|c|}
\hline $\begin{array}{l}\text { Nama } \\
\text { event }\end{array}$ & $\begin{array}{l}\text { Wakt } \\
\text { u }\end{array}$ & $\begin{array}{l}\text { Nama } \\
\text { Tempa } \\
\text { t }\end{array}$ & $\begin{array}{l}\text { Kecamat } \\
\text { an }\end{array}$ & $\begin{array}{l}\text { Kabupat } \\
\text { en }\end{array}$ & $\begin{array}{l}\text { Penyelengg } \\
\text { ara }\end{array}$ & Acara & $\begin{array}{l}\text { Hibura } \\
\text { n }\end{array}$ & $\begin{array}{l}\text { Keteranga } \\
\text { n }\end{array}$ & Kontak \\
\hline $\begin{array}{l}\text { Lomb } \\
\text { a } \\
\text { Gede } \\
\text { Gedea } \\
\mathrm{n} \\
\text { Duria } \\
\mathrm{n}\end{array}$ & $\begin{array}{l}19 \\
\text { Maret } \\
2015\end{array}$ & $\begin{array}{l}\text { Lapang } \\
\text { an }\end{array}$ & $\begin{array}{l}\text { Candimul } \\
\text { yo }\end{array}$ & $\begin{array}{l}\text { Magelan } \\
\mathrm{g}\end{array}$ & $\begin{array}{l}\text { BPPKP } \\
\text { Kabupatn } \\
\text { Magelang } \\
\text { dan } \\
\text { Kecamatan } \\
\text { Mungkid }\end{array}$ & $\begin{array}{l}\text { Lomba } \\
\text { gede } \\
\text { gedean } \\
\text { durian } \\
\text { diukur } \\
\text { dari } \\
\text { volume } \\
\text { isi } \\
\text { lingkar } \\
\text { an. }\end{array}$ & - & $\begin{array}{l}\text { Syarat dan } \\
\text { ketentuan: } \\
\text {...... }\end{array}$ & $\begin{array}{l}\text { Langen: } \\
085643773 \\
524\end{array}$ \\
\hline$\ldots$. & $\ldots$. & $\ldots$. & & & $\ldots$. & $\ldots$ & $\ldots$ & $\ldots$. & $\ldots$. \\
\hline
\end{tabular}

Tabel 14.

Informasi Restaurant bentuk Normal ke-1 dengan Penyederhanaan Atribut

\begin{tabular}{|c|c|c|c|c|c|c|c|c|c|c|c|c|}
\hline $\begin{array}{l}\text { Judul } \\
\text { info }\end{array}$ & $\begin{array}{l}\text { Tgli } \\
\text { nfo }\end{array}$ & $\begin{array}{l}\text { namar } \\
\text { esto }\end{array}$ & $\begin{array}{l}\text { fot } \\
\text { oR }\end{array}$ & $\begin{array}{l}\text { beritaRest } \\
\text { o }\end{array}$ & $\begin{array}{l}\text { alamat } \\
\text { Resto }\end{array}$ & Desa & $\begin{array}{l}\text { Kecam } \\
\text { atan }\end{array}$ & $\begin{array}{l}\text { Kabup } \\
\text { aten }\end{array}$ & $\begin{array}{l}\text { tlpR } \\
\text { esto }\end{array}$ & $\begin{array}{l}\text { Pem } \\
\text { ilik }\end{array}$ & $\begin{array}{l}\text { hpPemil } \\
\text { ik }\end{array}$ & Email \\
\hline $\begin{array}{l}\text { Selam } \\
\text { at } \\
\text { datang } \\
\text { di } \\
\text { Sekar } \\
\text { Kedat } \\
\text { hon }\end{array}$ & $\begin{array}{l}\text { Mar } \\
\text { ch 6, } \\
2016\end{array}$ & $\begin{array}{l}\text { Sekar } \\
\text { Kedath } \\
\text { on }\end{array}$ & $\begin{array}{l}\text { Fot } \\
0\end{array}$ & $\begin{array}{l}\text { Sekar } \\
\text { Kedhaton } \\
\text { Restaurant } \\
\text { adalah } \\
\text { tempat ...... }\end{array}$ & $\begin{array}{l}\text { Jl. Raya } \\
\text { Borobu } \\
\text { dur } \quad \mathrm{km} \\
2,5\end{array}$ & $\begin{array}{l}\text { Borob } \\
\text { udur }\end{array}$ & $\begin{array}{l}\text { Mungki } \\
\mathrm{d}\end{array}$ & $\begin{array}{l}\text { Magela } \\
\text { ng }\end{array}$ & $\begin{array}{l}0293 \\
386 \\
868\end{array}$ & $\begin{array}{l}\text { Betta } \\
\text { Fara } \\
\text { h, SE }\end{array}$ & $\begin{array}{l}0811251 \\
874\end{array}$ & $\begin{array}{l}\text { betta.far } \\
\text { ah } \\
@ \text { yahoo } \\
\text {.com }\end{array}$ \\
\hline $\begin{array}{l}\text { Selam } \\
\text { at } \\
\text { datang } \\
\text { di } \\
\text { Sekar } \\
\text { Kedat } \\
\text { hon } \\
\text {... }\end{array}$ & $\begin{array}{l}\text { Mar } \\
\text { ch 6, } \\
2016\end{array}$ & $\begin{array}{l}\text { Sekar } \\
\text { Kedath } \\
\text { on }\end{array}$ & $\begin{array}{l}\text { Fot } \\
0\end{array}$ & $\begin{array}{l}\text { Sekar } \\
\text { Kedhaton } \\
\text { Restaurant } \\
\text { adalah } \\
\text { tempat ...... }\end{array}$ & $\begin{array}{l}\text { Jl. Raya } \\
\text { Borobu } \\
\text { dur } \mathrm{km} \\
2,5\end{array}$ & $\begin{array}{l}\text { Borob } \\
\text { udur }\end{array}$ & $\begin{array}{l}\text { Mungki } \\
\text { d }\end{array}$ & $\begin{array}{l}\text { Magela } \\
\text { ng }\end{array}$ & $\begin{array}{l}0293 \\
386 \\
005\end{array}$ & $\begin{array}{l}\text { Betta } \\
\text { Fara } \\
\text { h, SE }\end{array}$ & $\begin{array}{l}0851004 \\
18424\end{array}$ & $\begin{array}{l}\text { betta.far } \\
\text { ah } \\
\text { @yahoo } \\
\text {.com }\end{array}$ \\
\hline$\ldots$ & $\ldots$ & $\ldots$ & $\ldots$ & $\ldots$ & $\ldots$ & & & & $\ldots$ & $\ldots$ & $\ldots$ & $\ldots$ \\
\hline
\end{tabular}

Untuk memudahkan identifikasi ketergantungan fungsional, kami tambahkan atribut yang bersifat tunggal (single valued attribute). Sebagai contoh obyekNO, kategoriNO, desaNO, kecNO, kabNO, fotoNO, tujuanNO, fasilitasNO, eventNO, kontakNO, restoNO, judulNO, pemilikNO. Atribut tujun berisi nama obyek wisata, sehingga tidak perlu menulis ulang nama obyek tetapi mengambil pengenalnya yaitu obyekNO. Pilihan sebagai primary key (kunci pengenal) adalah obyekNO, kategoriNO, tujuanNO, fasilitasNO untuk Tabel 12, dan pilihan sebagai kunci pengenal pada Tabel 13 adalah eventNO, tanggal, kontakNO, sedangkan pada Tabel 14 pilihan kunci pengenalnya adalah judulNo, restoNo, tglinfo.

Identifikasi ketergantungan fungsional pada Tabel 12.

FD1: obyekNO, tujuanNO $\rightarrow$ jarakkm

FD2: obyekNO $\rightarrow$ namaobyek, kategori, alamat, desa, kecamatan, kabupaten, fotoobyek, gps-south, gps-east, sejarahketerangan, fasilitasobyek (ketergantungan parsial)

FD3: kategoriNO $\rightarrow$ kategori (ketergantungan transitif)

FD4: fasilitasNO $\rightarrow$ fasilitasobyek (ketergantungan transitif)

FD5: desaNO $\rightarrow$ desa $\quad$ (ketergantungan transitif)

FD6: kecNO $\rightarrow$ kecamatan $\quad$ (ketergantungan transitif)

FD7: kabNO $\rightarrow$ kabupaten $\quad$ (ketergantungan transitif)

FD8: fotoNO $\rightarrow$ fotoobyek $\quad$ (ketergantungan transitif)

Identifikasi ketergantungan fungsional pada Tabel 13.

FD1: eventNO, kontakNO $\rightarrow$ kontak

FD2: eventNO $\rightarrow$ namaevent, waktu, namatempat, kecamatan, kabupaten, penyelenggara, acara, hiburan, keterangan (ketergantungan parsial)

FD3: kecNO $\rightarrow$ kecamatan (ketergantungan transitif)

FD4: kabNO $\rightarrow$ kabupaten (ketergantungan transitif)

Identifikasi ketergantungan fungsional pada Tabel 14.

FD1: judulNO, restoNO, tglinfo $\rightarrow$ judulinfo, beritaResto

FD2: restoNO $\rightarrow$ namaresto, fotoR, alamatResto, desa, kecamatan, kabupaten, pemilik (ket. parsial)

FD3: pemilikNO $\rightarrow$ pemilik, email (ketergantungan transitif) 
FD4: desaNO $\rightarrow$ desa

FD5: kecNO $\rightarrow$ kecamatan

FD6: kabNO $\rightarrow$ kabupaten (ketergantungan transitif)

(ketergantungan transitif)

(ketergantungan transitif)

Dalam proses mengidentifikasi primary key (pengenal), kita dapat menemukan entitas (tabel) yang disebut strong entity (kuat), dan entitas yang disebut weak entity (lemah). Pengenal dari entitas lemah hanya dapat diidentifikasi ketika memetakan entitas dan hubungannya dengan pemiliknya. Dalam kasus ini, tlpResto dan hpPemilik merupakan atribut yang menjadi entitas lemah.

FD7: restoNO, tlpResto (entitas lemah)

FD8: pemilikNO, hpPemilik (entitas lemah)

Berdasarkan ketergantungan fungsional tersebut, dengan menghilangkan ketergantungan parsial maka diperoleh relasi dalam bentuk normal ke-2 sbb:

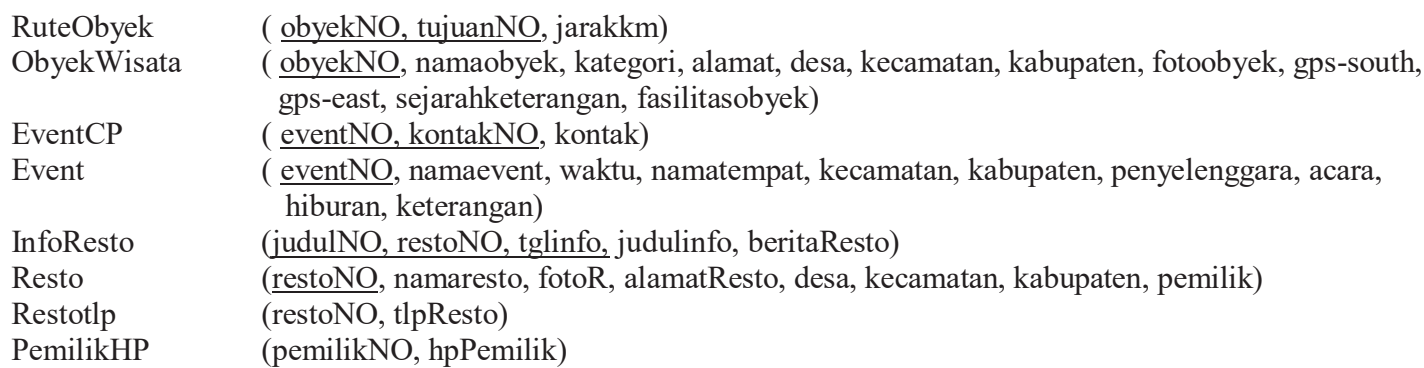

Tabel atau relasi yang berada pada bentuk normal ke-2 tersebut, belum memenuhi bentuk nomral ke-3 sehingga perlu dilakukan normalisasi tahap ke-3 dengan menghilangkan ketergantungan transitif maka diperoleh tabel atau relasi dalam bentuk normal ke-3 sbb:

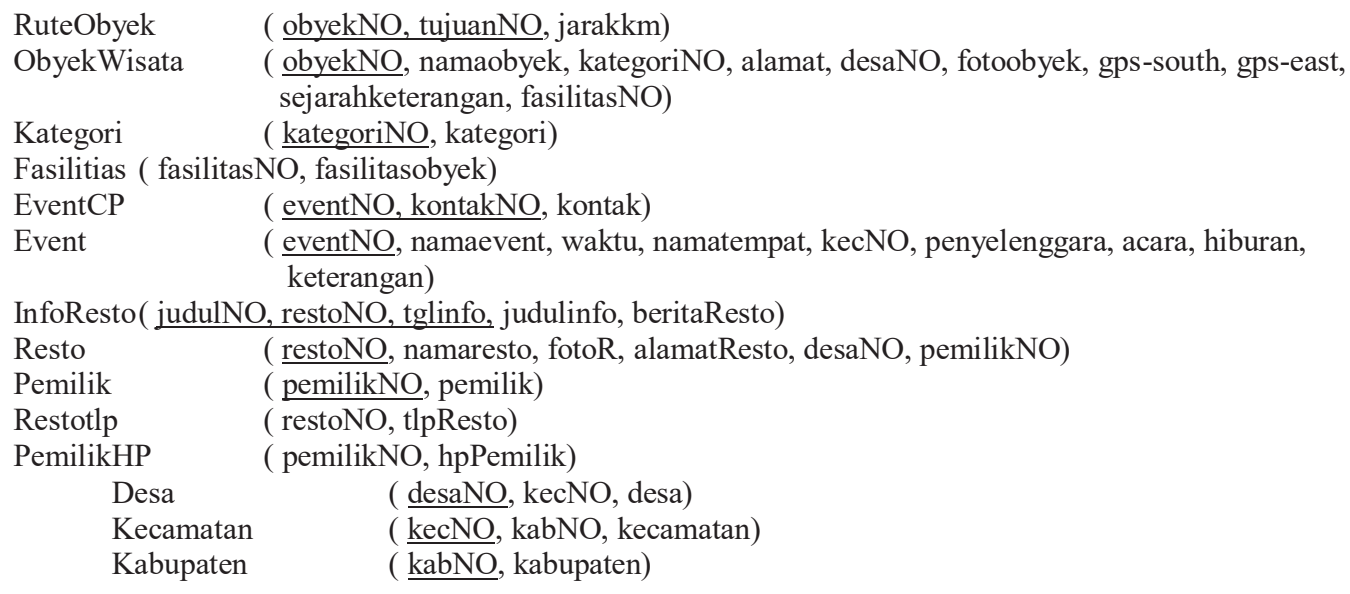

\section{Pemodelan Basis Data}

Model basis data yang digunakan adalah entity relationshp diagram (ERD). Model basis data konseptual ini dibuat dengan keberadaannya yang independen dari rincian implementasi sistem yang berhubungan dengan DBMS, bahasa pemrograman, platform perangkat keras, masalah kinerja dan pertimbangan fisik lainnya. Berdasarkan hasil normalisasi data pada tahap ke-3, maka model basis data yang terbentuk adalah seperti pada Gambar 4 berikut ini. 


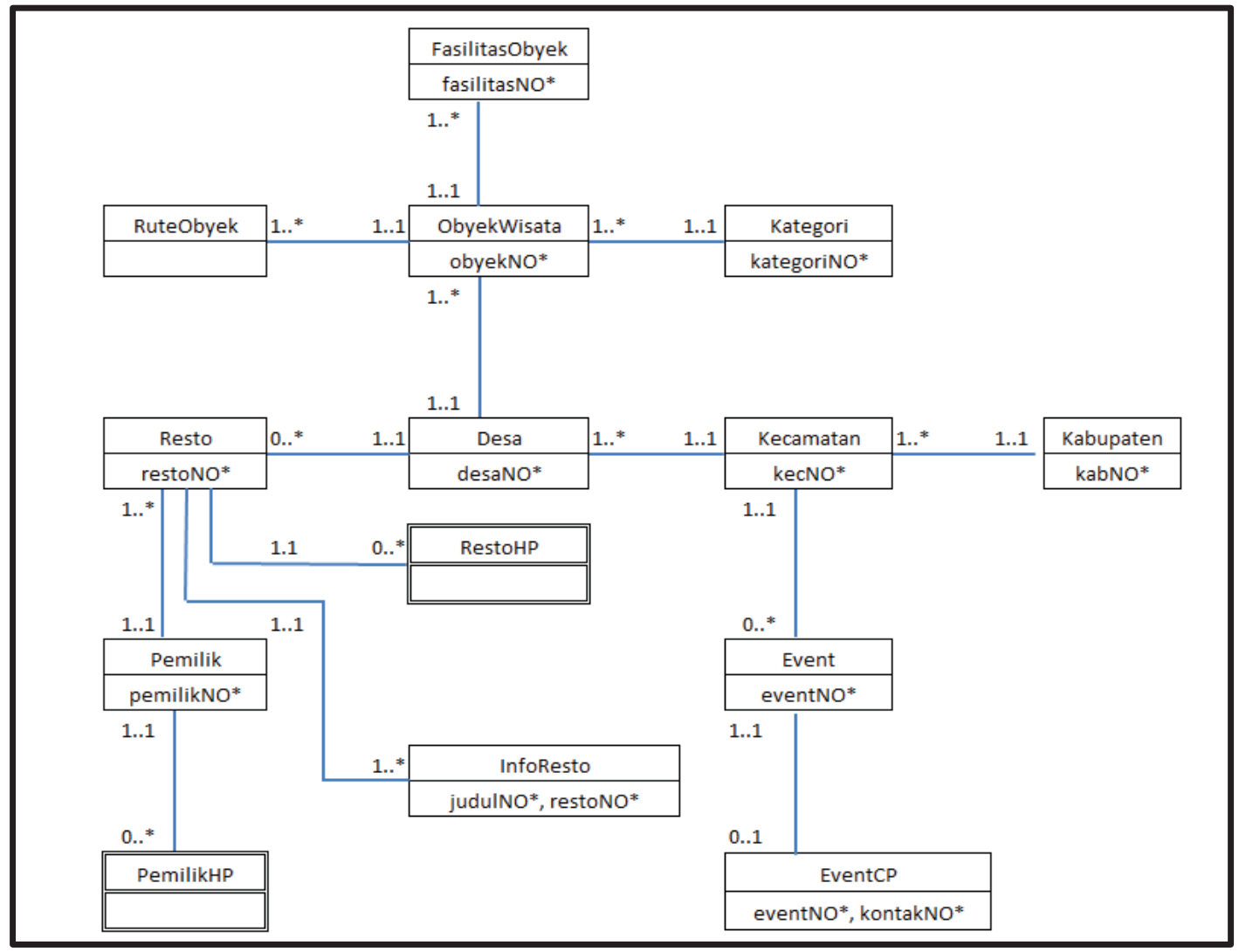

Gambar 4. Entity Relationship Diagram - Model Basis Data yang dihasilkan

\section{Simpulan}

Melalui pengumpulan kebutuhan untuk melakukan analisis data obyek wisata di Kabupaten Magelang diperoleh bahwa terdapat beberapa cara yang sama dan cara yang berbeda dalam melakukan penyimpanan datanya, dan terdapat kerangkapan data. Dalam mendukung implementasi sistem, data harus disimpan dengan menghilangkan terjadinya duplikasi data, dan hasil yang diperoleh adalah:

a. Melalui tahapan normalisasi, relasi atau tabel yang dihasilkan sebanyak 14 tabel dalam bentuk normal ke-3, sehingga tidak terjadi ketergantungan parsial dan ketergantungan transtif.

b. Model basis data yang dihasilkan ditunjukkan pada gambar 4 dengan derajat keterhubungan berapasangan antar dua relasi (binary relationship).

c. Basis data yang dirancang mencerminkan kapan dan bagaimana data itu harus disimpan tanpa terpengaruh oleh sistem yang akan diimplementasikan.

\section{Daftar Pustaka}

Connoly, T. \& Begg, C. (2010). Database Systems: A Practical Approach to Design, Implementation, and Management, Fourth Edition, Addison Wesley.

Ofobruku, S.A. \& Obabanjo, B.N. \& Theabunike, O.B. (2013), Utilisation of GIS Technology for Tourism Management in Victoria Island Lagos, European Scientific Journal, edition vol.9, No.3 ISSN: 1857.

Garmin.com (2015). What is GPS?, diakses pada Desember 2015 dari halaman website http://www.garmin.com/aboutGPS.

Hoffer, J.A. \& Ramesh, V. \& Topi, H. (2011). Modern Database Management, Pearson Eduction.

Valacich, S. \& Joseph (2012). Essentials of Systems Analysis and Design, Fifth Edition, Pearson Education, Inc., publishing as Prentice Hall.

www.prm.nau.edu/prm300/what-is-tourism-lesson.htm (2013). Introduction - What is Tourism ? Online Lesson. Parks and Recreation Management Program Department of Geography, Planning and Recreation, College of Social and Behavioral Sciences

Northern Arizona University. Diakses pada bulan Mei 2016. 